\title{
Aproximações entre Paulo Freire e Theodor Adorno em torno da educação emancipatória
}

\author{
Damião Bezerra Oliveira ${ }^{1}$ \\ ORCID: 0000-0002-8247-8803 \\ Izan Rodrigues de Souza Fortunato ${ }^{1}$ \\ ORCID: 0000-0003-1891-3628 \\ Waldir Ferreira de Abreu ${ }^{1}$ \\ ORCID: 0000-0002-0245-9072
}

\section{Resumo}

Buscou-se, em um movimento aproximativo entre Freire e Adorno, compreender como é possivel constituir a ação educativa como ato que favorece a emancipação, a libertação e a autonomia do ser humano, mediante a seguinte indagação: quais são os pontos de articulação entre Freire e Adorno no tocante ao conceito de educação emancipatória? A pesquisa é caracterizada como teórico-reflexiva e bibliográfica, tomando, como fontes principais de análise, obras de Freire e Adorno e, complementarmente, os escritos de autores relevantes para o desenvolvimento do tema. Freire e Adorno contrapõem as suas perspectivas críticas ao pensamento tradicional concernente à educação vigente, problematizam as teorias tradicionais e buscam superá-las em nome da promoção da emancipação, da autonomia e da libertação, reconhecidas como objetivos formativos fundamentais. Os dois pensadores mostram-se vigilantes em relação às possibilidades regressivas de uma formação que adeque e conforme o educando ao mundo instituído, mantendo-o oprimido, reprodutor, um mero consumidor de conteúdos didatizados. A educação emancipatória insurge-se contra a formação de "um ser menos", coisificado 2 em sua subjetividade, incapaz de ser ou de lutar para vir a ser o protagonista, o construtor de sua própria existência, com a finalidade de fazer emergir uma forma de vida em comum que reconheça a pluralidade dos modos de ser, o que é demandado pela cidadania democrática da contemporaneidade.

\section{Palavras-chave}

Formação - Educação emancipatória - Theodor Adorno - Paulo Freire.

\footnotetext{
1- Universidade Federal do Pará, Belém, PA, Brasil. Contatos: damiao@ufpa.br; cauinyan@gmail.com; awaldir@ufpa.br

2- A coisificação ou reificação dos sujeitos, em consonância com a tradição de teoria crítica, pode ser entendida aqui como o processo de socialização alienado e alienante do qual resultam pessoas embrutecidas, que são tratadas como se fossem coisas, havendo, pois, uma troca de lugar, visivel no sistema de reprodução fetichista da sociedade capitalista, que faz do capital o sujeito e do ser humano, 0 objeto. A reificação necrófila ou o assujeitamento do sujeito aparecem, entre outras, na obra Pedagogia do oprimido (FREIRE, 1987) e em Dialética do esclarecimento (ADORNO; HORKHEIMER, 1985).
} 


\section{Convergences of Paulo Freire and Theodor Adorno around emancipatory education}

\section{Abstract}

This study was an attempt to bring together Freire and Adorno in order to understand how one can perform an educational action capable of fostering emancipation, liberation, and autonomy. The following enquiry guided this study: what are the confluences between Freire and Adorno insofar as emancipatory education is concerned? This study is a theoreticalreflexive approach to a bibliographical and its main sources are the works of Freire and Adorno as well as the works of other authors relevant to the discussion of the theme. Freire and Adorno contrast their critical perspectives with the traditional thought that permeates current education thinking and practice, problematize traditional educational theories, and try to go beyond them in order to promote emancipation, liberation and autonomy, thought of as fundamental formative objectives. Both thinkers are watchful on the regressive possibilities of an education that shapes and fits a learner into the world as it is established, oppresses and makes of the learner but a repeater and consumer of didactic contents. Emancipatory education rebels against the upbringing of a "lesser being", whose subjectivity was objectified, and who is incapable of being the protagonist, or of fighting to become a protagonist and maker of its own existence. Thus, emancipatory education aims at bringing forth a common life form that recognizes the plurality of ways of being; as is required by the contemporary democratic citizenship process.

\section{Keywords}

Education - Emancipatory education - Theodor Adorno - Paulo Freire.

\section{Introdução}

Theodor Adorno e Paulo Freire podem ser considerados pensadores fundamentais para se compreender um projeto emancipatório de formação dos seres humanos, sem ignorar as peculiaridades socioculturais e históricas de cada autor. Ambos contribuíram significativamente com uma filosofia acerca da formação humana, colocando em dúvida as determinações ontológicas e gnosiológicas que deram sustentação à tradição educacional instituída, particularmente a que se estabeleceu nos tempos modernos e ganhou o estatuto de senso comum, soterrando, quase sempre, o potencial crítico e reflexivo do pensar que impulsiona a constituição de pessoas autônomas e emancipadas (ADORNO, 1995, 2009; ZUIN; PUCCI; OLIVEIRA, 1999). 
A possibilidade de uma educação devotada ao exercício da liberdade ${ }^{3}$ de ser e pensar e, portanto, construída contra as investidas autoritárias e/ou totalitárias de determinados arranjos de poder é um dos núcleos da filosofia da educação dos dois autores. Freire, sem se limitar a isso, toma como horizonte histórico antagônico da sua práxis o regime ditatorial brasileiro e latino-americano; ao passo que Adorno se assombra com o regime nazista que se desenvolve na Europa, principalmente na Alemanha.

Assim, este artigo visa lançar pistas iluminadoras acerca da emancipação humana, tendo como referência as confluências entre o pensamento crítico de Theodor Adorno e de Paulo Freire, na medida em que ambos defendem projetos de existência pautados na liberdade e autonomia humana, elementos fundamentais da conscientização, da reflexão crítica da consciência de si, em sua relação com os outros no mundo (ADORNO, 1995; ADORNO; HORKHEIMER, 1985; FREIRE, 1987).

Apesar de as instituições apresentarem, por vezes, a realidade existente como um dado quase inalterável, o mundo humano precisa ser entendido como resultado de ações que se desenvolvem na história mediante decisões livres dos entes humanos, em tensão, é verdade, com as condições dadas. Assim, a existência constitui-se, em grande parte, em um horizonte de contingência, de abertura à autoconstituição do ser-mais do homem (FREIRE, 1987).

Partindo de uma ontologia do ser humano inacabado e inconcluso, em processo de gestação do mundo com os outros, é possivel compreender que uma das ideias-força de Freire, compartilhada por Adorno, consiste em conferir à educação o potencial de transformação consciente do ser humano e do seu mundo. Nos dois autores, a ação educativa crítica pode exercer um desejável papel de fermento transformador e disruptivo da educação instituída. Para que a transformação ocorra, deve-se incentivar o educando a não se conformar ou se sujeitar ao status quo.

A condição de assujeitamento pode prosperar caso não haja o devido aparato de crítica e resistência, uma vez que são potencializadoras de uma educação emancipatória. 0 enfraquecimento da crítica compromete o processo educacional, podendo culminar na formação pusilânime do educando e na sua desumanização.

Consonante com o pensamento adorniano, Freire (1987), em investida crítica à opressão, mostra que há trilhas conducentes à libertação do educando que podem leválo a sair da condição de oprimido, de "ser menos" em sua humanidade. 0 caminho da emancipação deve ser construído por meio da superação da educação não crítica que sustenta a realidade opressora, visando à elevação ontológica do educando.

\footnotetext{
3- Para além da ideia de livre arbítrio, capacidade de escolha, não constrangimento ou de independência individual, pode-se apontar como uma chave para pensar o complexo conceito de liberdade, a apropriação crítica, de Freire e Adorno, da Fenomenologia do espírito (parágrafo 178): "Independência e dependência da consciência-de-si, dominação e escravidão" (HEGEL, 1992, p. 126), referida tanto na Pedagogia do oprimido quanto na Dialética do esclarecimento. Portanto, a liberdade só pode ser compreendida pela relação dialética entre sujeito e objeto no processo de libertação daquele da submissão/opressão como ente historicamente situado. Por meio da práxis social emancipatória, a subjetividade pode se constituir autonomamente, mas não de modo absoluto, pois o sujeito, na sua historicidade sociocultural, mantém relações fundamentais com os outros no mundo. Deve-se lembrar que, em Adorno, não só o mundo impõe limites a uma possível vontade autônoma e orientada à ação - consciente e racionalmente -, mas também o inconsciente. Todos esses conceitos e noções remetem uns aos outros e só podem ser compreendidos em conjunto e nas suas interconexões (FREIRE, 1987; ADORNO; HORKHEIMER, 1985).
} 
Em ligação com o exposto, procura-se compreender, em um movimento aproximativo de Adorno e Freire, como é possível constituir uma educação emancipatória do ser humano, situado histórica e socialmente, em luta contra a dominação e os assujeitamentos derivados das relações tensas e contraditórias com a natureza, mas também com os condicionamentos do mundo administrado.

A nosso ver, as pesquisas acerca da formação do ser humano, por tocarem a dimensão prática da existência e se vincularem às preocupações ético-políticas que são tão fundamentais para a vida em sociedade, justificam-se, ainda, pelas possíveis contribuições ao debate acerca da escolha dos fins aos quais deve se dedicar a educação em face do crescimento de atitudes fundamentalistas, dogmáticas, que fomentam a barbárie, ameaçam a liberdade, inibem o pensamento crítico-reflexivo e a pluralidade de modos de existir.

\section{Formação crítica e emancipatória em Adorno}

Ao se posicionar a favor da emancipação do educando, Adorno reconhece, a um só tempo, que a história pode tanto progredir quanto regredir, de modo que, diante dessa contingência, passa-se a conviver com o risco da barbárie, não como uma hipótese distante, mas enquanto "repetição" do que ocorreu na Alemanha nazista durante a Segunda Guerra Mundial, sendo os campos de concentração seu exemplo icônico. Nesses espaços de morte e crueldade, suspendeu-se qualquer razoável senso de humanidade, uma vez que muitos homens foram colocados na condição de simples meios, de objetos.

A supressão do outro e a eliminação de seres humanos negados na sua humanidade consagram a morte e a necrofilia como orientadoras de um projeto político. Desse modo, a barbárie emergente desse acontecimento não se confunde com o que alguns antropólogos evolucionistas consideraram como uma fase embrionária do homem, nem pressupõe a ausência de acesso à ciência e tecnologia como marcadores do estágio de civilização.

Por isso, a "barbárie civilizada" representa um certo paradoxo, pois reúne e aproxima o que historicamente parece incompativel. Os instintos e a inconsciência não são anulados, ou mesmo controlados e contidos definitivamente pela polidez e humanização produzidas pelo movimento de civilização, porque este carrega consigo as forças contrárias. 0 ente humano constitui-se, inelutavelmente, na tensão e contradição entre o "dionisíaco" e o "apolíneo", empregando uma terminologia nietzschiana:

Apolo e Dionísio, vincula-se a nossa cognição de que no mundo helênico existe uma enorme contraposição, quanto a origens e objetivos, entre a arte do figurador plástico [Bildner], a apolínea, e a arte não-figurada [unbildlichen] da música, a de Dionísio: ambos os impulsos, tão diversos, caminham lado a lado, na maioria das vezes, em discórdia aberta e incitando-se mutuamente a produções sempre novas, para perpetuar nelas a luta daquela contraposição sobre a qual a palavra comum "arte" lançava apenas aparentemente a ponte; até que, por fim, através de um miraculoso ato metafísico da "vontade" helênica, apareceram emparelhados um com o outro, e nesse emparelhamento tanto a obra de arte dionisíaca quanto a apolínea geraram a tragédia ática. (NIETZSCHE, 1992, p. 27). 
$\mathrm{Ou}$, para trazer uma referência mais próxima da filosofia de Adorno, pode-se evocar o célebre confronto de Eros e Thanatos, de que fala Freud ao se referir à civilização:

Ela nos apresenta a luta entre Eros e morte, instinto de vida e instinto de destruição, tal como se desenrola na espécie humana. Essa luta é o conteúdo essencial da vida, e por isso a evolução cultural pode ser designada, brevemente, como a luta vital da espécie humana. (FREUD, 2010, p. 91).

Em todos os casos, enfatiza-se certo componente trágico dinamizando a cultura humana. Ora, se for assim, então a educação definida como contenção e refinamento do que há de "animal" no homem não representa uma garantia de emancipação, pois a própria racionalidade, como produtora de clareza e distinção, acaba por se endurecer como razão calculista que se identifica com o domínio técnico, fazendo ressurgir com mais força ainda o que tenta conter.

Contudo, o "pessimismo" de Adorno com os excessos desumanizantes da racionalização científico-tecnológica da teoria tradicional positivista não o torna cético com relação à plausibilidade de emancipação, que se vislumbra como possibilidade de um tipo de formação subjetiva fundada no pensamento que precisa ser reeducado. A razão deve explorar as potencialidades adormecidas, domesticadas, sua natureza usurpada pela operação fetichizante da tecnologia, que a transformou em razão instrumental. 0 exagerado esforço da racionalização dirigido à dominação da natureza e de homens coisificados tornou a razão cega aos fins ético-políticos, à humanização, ou, nos termos de Freire (1987), à autoconstituição do ser-mais do ente humano.

No que concerne ao lugar da educação formal em uma sociedade democrática, Adorno deixa apreender, na citação seguinte, que não é suficiente a universalização do acesso à escola para que se dê a emancipação do sujeito humano:

Para nos expressarmos em termos corriqueiros, isto não significa emancipação mediante a escola para todos, mas emancipação pela demolição da estruturação vigente em três níveis e por intermédio de uma oferta formativa bastante diferenciada e múltipla em todos os níveis, da pré-escola até o aperfeiçoamento permanente, possibilitando, deste modo, o desenvolvimento da emancipação em cada indivíduo. (ADORNO, 1995, p. 170).

Portanto, o projeto liberal de emancipação por meio de uma escola para todos deixa de considerar que há um elemento estrutural inerente à própria lógica institucional da escolarização, que limita e impede o desenvolvimento dos sujeitos tendo em vista a sua libertação das tutorias.

Assim, a emancipação se define em um contexto complexo e contraditório. Há um componente "trágico" da cultura que impede a possibilidade de pensar a educação se resolvendo em um momento de repouso, de síntese, que finalmente faria vir à tona o ente humano integral e pleno. Isso não ocorre porque a liberdade do sujeito se move no espaço da contingência. No esforço de resistência contra a regressão à "barbárie", podem se imiscuir ações educativas constitutivas das subjetividades que desfiguram o objetivo legítimo da educação emancipatória. 
Sob esse aspecto, um homem dono de si, emancipado por um processo educativo de conscientização, não se coaduna com a concepção "trágica" de Adorno, que reconhece a existência de uma tensão permanente entre Eros e Thanatos. De algum modo, o freudismo se sobrepõe à promessa revolucionária do marxismo. Resta sempre uma força inconsciente que, de alguma maneira, impossibilita ou compromete a autonomia do sujeito (FREUD, 2010, 2011).

Assim, a autonomia interpõe-se entre a liberdade, a capacidade consciente de decisão do sujeito e o espaço de condicionamento sobre o qual o agente não exerce controle. Daí porque certo espaço de objetivação e alienação se apresentar como constitutivo dos indivíduos nas suas relações com os outros e com o mundo, tornando impossivel a total reconciliação do ente humano consigo próprio e com a realidade natural e cultural.

É, pois, nessa trama que se articulam os conceitos de liberdade, autonomia e emancipação em Adorno. A teoria crítica desse autor constrói-se em diálogo com o pensamento iluminista de Kant, com a filosofia marxista, mas também com a psicanálise de Freud, sem que, no entanto, a filosofia adorniana possa ser compreendida em estrita consonância com qualquer um desses referenciais.

É possivel identificar, internas aos indivíduos, poderosas forças formadoras da personalidade, que os movem nas suas ações na história e que seriam anteriores às lutas de classe ou qualquer outro tipo de confronto. A relação entre subjetividade e objetividade não seria explicada adequadamente por uma teoria que coloca em conexão dialética infra e superestrutura.

Desse modo, a educação moderna instituída, na medida em que não é capaz de enxergar os aspectos ressaltados anteriormente, mostra-se limitada ou mesmo impedida de elevar os entes humanos do seu "estado de menoridade" a uma situação de autêntica emancipação, aumentando, assim, a probabilidade de recaída na barbárie, como a que se constatou na Segunda Guerra Mundial, nos emblemáticos casos do campo de concentração de Auschwitz e do massacre nuclear das cidades de Hiroshima e Nagasaki.

Embora seja possível evocar a regressão aos instintos e o irracionalismo como motivadores de ações cruéis, desumanas e destrutivas, a organização sistemática e tecnológica de tais atos indica a presença de um determinado tipo de racionalidade que atua como meio eficaz na execução dessas ações.

Há, portanto, um tipo de aliança entre forças instintivas e racionalidade que não se presta a produzir autonomia e emancipação, mas adaptação. Nota-se, portanto, a existência de um tipo de práxis produtiva negadora das forças emancipatórias e humanizadoras. Tal modalidade de racionalidade imiscui-se, por vezes, em diversos domínios da existência, inclusive no âmbito educacional. Daí a ponderação adorniana, segundo a qual:

A necessidade de tal adaptação, da identificação com o existente, com o dado, com o poder enquanto tal, gera o potencial totalitário. Este é reforçado pela insatisfação e pelo ódio, produzidos e reproduzidos pela própria imposição à adaptação justamente porque a realidade não cumpre a promessa de autonomia. (ADORNO, 1995, p. 43-44).

0 pensamento emancipador não despreza a realidade material, produtiva e corporal. Contudo, não se subordina ao cálculo, à busca da melhor performance, à adaptação às 
regras como fim mesmo do viver e, por consequência, não renuncia à atitude crítica e às preocupações ético-políticas que devem orientar a dimensão prática da existência.

A emancipação dos sujeitos é um projeto histórico que não ganha sentido tão somente em situações extremas de ameaça à liberdade e à humanização. Por isso, o combate à barbárie deve ser um esforço constante e continuado, pois ela pode imiscuir-se insidiosamente nas relações humanas mais cotidianas que orientam a formação dos indivíduos.

Subjetividades adaptáveis, educadas para aderir às normas e determinações das instituições sociais, que se colocam em face do mundo constituído como se esse fosse uma coisa dada, perdem a capacidade de questionar, de se revoltar, de contestar a ordem estabelecida, fechando-se aos projetos utópicos que se esforçam para construir criativamente um mundo mais humano.

No âmbito educacional escolar, as formas regressivas de liberdade, negadoras da autonomia, expressam-se nas relações verticalizadas que valorizam a adequação tácita dos agentes às diretrizes pedagógicas prescritas e impostas. As inter-relações formativas podem ser permeadas, em diversos momentos, por uma racionalidade técnico-administrativa que produz eficazmente a submissão intelectual dos sujeitos, de modo a interditar as suas possibilidades de emancipação.

Portanto, a "barbárie educativa”, como ação prolongada e sub-reptícia, insinua-se, por vezes, no exercício das ações cotidianas, seccionando o exercício do pensamento crítico, sedimentando e naturalizando a condição de "ser menos" dos sujeitos (FREIRE, 1987). Consagra-se a domesticação e a alienação, que são barreiras à conquista do direito à cidadania intelectual e promotoras de subalternidade dos sujeitos ao status quo.

Adorno (1995, p. 71) enfatiza que: “[...] na incapacidade do pensamento em se impor, já se encontra à espreita o potencial de enquadramento e subordinação a uma autoridade qualquer, do mesmo modo como hoje, concreta e voluntariamente, a gente se curva ao existente".

Para Adorno, a educação tecnicizada não abre possibilidades ao educando de ser arquiteto de sua cidadania intelectual, não leva em consideração o seu potencial de sujeito social criativo e crítico, mas antes o neutraliza ao favorecer a educação como "mera reprodução intelectual cognitiva”, de acordo com as necessidades do capitalismo hegemônico.

A proposta pedagógica instituída em sua prática mais basilar consiste em inculcar e circunscrever o que deve ser absorvido e internalizado por meio dos conteúdos formativos prescritos, para que o educando os processe e, posteriormente, os reproduza como conhecimento adquirido, sem o mínimo de exercício "ruminador" necessário à maturação do exercício crítico. A resistência a isso é indispensável e pode ocorrer pelo impulso crítico que leva o educando a ensaiar a ruptura com tal imposição pedagógica. Do aprofundamento desse gesto de emancipação, o educando assenhora-se da sua vida, pensando e agindo por si mesmo, mas sem abandonar a sua abertura ao outro, o que é indispensável a uma existência democrática e plural.

A esse propósito, Adorno (1995, p. 169) infere que:

A exigência de emancipação parece ser evidente numa democracia. Para precisar a questão gostaria de remeter ao início do breve ensaio kantiano intitulado "Resposta à pergunta: o que é esclarecimento?" Ali ele diz que a menoridade ou tutela e, deste modo, também a emancipação, 
afirmando que este estado de menoridade é autoinculpável quando sua causa não é a falta de entendimento, mas a falta de decisão e de coragem de servir-se do entendimento sem a orientação de outrem.

Assim, a crítica adorniana indica a falta de preocupação da educação vigente com a autonomia cognitiva do educando, para que ele persiga a emancipação no sentido kantiano de fazer uso de sua razão sem a orientação de outrem, a fim de exercer a racionalidade no contexto público, enquanto liberdade do sujeito social para manifestar-se sobre os vários aspectos da realidade, sejam políticos, culturais, ideológicos ou educacionais.

De modo que ver-se-á a "autoindulgência" intelectual patrocinada pelo programa pedagógico tradicional, que envolve o educando, sem se dar conta dos impasses de sua subalternidade; passivamente aceita o que é prescrito e determinado pelas diretrizes convencionais da tradição educacional, tornando-se, até certo ponto, culpável de sua subalternidade. Contudo, pode-se inquirir: até que ponto o educando é culpável diante de sua não emancipação em face dos parâmetros pedagógicos tradicionais?

A exigência da emancipação preconizada por Adorno tem forte sentido factual de uma recusa firme a todo e qualquer poder externo que de certo modo queira "colonizar" o intelecto do "outro" ou, no dizer freiriano, fazê-lo hospedeiro da consciência dominadora (FREIRE, 1987).

Além do mais, Adorno critica a sociedade industrial como um todo, considerando a lógica mercadológica que impulsiona a compulsão ao consumo, levando o sujeito social à coisificação, uma vez que a educação não crítica desfavorece o ato pedagógico emancipatório. A educação precisa ser problematizadora, de modo a levar adiante continuamente a sua crítica ao status quo.

\section{Perspectiva crítica libertadora freiriana}

Dando seguimento à aproximação entre Freire a Adorno, pode-se dizer que, no entendimento freiriano, a educação tem como missão precípua possibilitar a libertação do sujeito a fim de que ele seja cidadão e agente de transformação, tanto no âmbito educacional como no contexto social.

De acordo com o pensamento freiriano, o sujeito deve ser o protagonista de sua história social e cultural. Também deve ter como objetivo atingir o patamar intelectual e cognitivo de saída do estado de menoridade; para isso, deve insurgir-se e desinstalarse da estreita e intransitiva consciência mágica - coisificada e subjugada - para uma consciência libertadora, crítica, pensante e problematizadora, que permita o enfrentamento da realidade opressora.

Em tal enfrentamento, é necessário realizar o movimento contrário ao do ato pedagógico instrumentalizado pela técnica, em direção a uma atitude de crítica ponderativa que, por sua vez, deverá conduzir o sujeito - compreendido como ser no mundo e em relação com os outros - no esforço criativo em direção à libertação humanizadora. Esse deve ser o sentido ontológico e gnosiológico da formação libertadora.

Deve-se ressaltar, portanto, que, em Freire (1987), a autêntica ação educativa jamais se confunde com a operação de adestrar o educando. Ora, tanto na ótica freiriana 
quanto na adorniana, a finalidade essencial da formação não pode ser outra que a emancipação intelectual e a produção da liberdade dos sujeitos. Como atividade relacional desses, a liberdade põe-se em movimento, sendo processo de libertação em relação ao condicionamento histórico, social, político, ideológico e cultural. Os sujeitos não podem delegar a responsabilidade da sua formação aos outros, mas antes precisam se engajar pessoalmente no esforço coletivo por humanização e cidadania.

Como parte fundamental do ato pedagógico libertador, apresenta-se a necessidade de desobstrução do itinerário intelectual do educando que produz a emancipação cognitiva, a capacidade de pensar criticamente, que é indispensável à orientação das ações na vida prática, nas decisões de ordem ético-políticas.

Portanto, a emancipação só ganha sentido como conquista que envolve consciência e mundo, teoria e prática. Nas palavras de Freire (1987, p. 15):

A consciência do mundo e a consciência de si crescem juntas e em razão direta; uma é a luz interior da outra, uma comprometida com a outra. Evidencia-se a intrínseca correlação entre conquistar-se, fazer-se mais si mesmo, e conquistar o mundo, fazê-lo mais humano.

0 ato pedagógico libertador nunca deixa o sujeito em processo de libertação como mero espectador. 0 exercício da liberdade no espaço compartilhado pelos sujeitos exige atuação efetiva. Não se pode pensar a humanização, em Freire, como algo que se realizaria na interioridade da consciência. A objetividade do mundo alia-se, dialeticamente, à subjetividade da consciência e esta, por sua vez, ganha sentido na dinâmica intersubjetiva que se desenvolve no mundo.

No entanto, a crítica só ganha sentido de libertação quando se efetiva como práxis, que é, por si, portadora de poder formativo. Nesse sentido, o modelo educativo tradicional mostra-se limitador, entre outras razões, por separar consciência de mundo, teoria de prática, subjetividade de intersubjetividade. Por consequência, em tal modelo, mesmo quando se fala de emancipação e autonomia, elas circunscrevem o seu sentido ao âmbito da mera individualidade solipsista.

A dissociação entre teoria e prática da racionalidade pedagógica instituída, acabou por privilegiar, nas relações de ensino-aprendizagem, os elementos técnicos e metodológicos em detrimento do potencial formativo das relações intersubjetivas, dos elementos criativos, singulares e contingentes, presentes nas relações didático-pedagógicas. Secundarizam-se, desse modo, os elementos ético-políticos da educação em nome da dimensão técnico-produtiva.

Assim, essa racionalidade tecnicista favorece a desumanização ao privilegiar a eficiência técnica, identificada ideologicamente com o progresso e a modernização. Contudo, um olhar mais atento e crítico poderá desvendar que esse tipo de discurso garante práticas que escondem uma espécie de barbárie educativa e civilizada, em simbiose com o poder hegemônico e a razão instrumental que estão a serviço do capitalismo.

Em Freire (1987), a libertação e a emancipação contrapõem-se à lógica pragmática do capital que, no seu afã massificante, desconsidera a singularidade dos sujeitos. Essa é uma das faces da desumanização contra a qual a educação deve se insurgir, a fim de fortalecer a vocação ontológica do homem a "ser mais" como sujeito inconcluso e inacabado. 
Esse ideal de libertação coaduna-se com a vida democrática participativa e plural, que reconhece o direito de múltiplos modos de ser, pensar e sentir. 0 reconhecimento e respeito a esse tipo de sociabilidade é condição indispensável ao exercício da liberdade.

Que fique bem entendido: a pluralidade de modos de existir não pode favorecer a criação de "guetos", pois o diálogo é indispensável a qualquer educação que se pretenda libertadora.

Sobre esse ponto, Freire (1987, p. 15) reitera que:

Mas ninguém se conscientiza separadamente dos demais. A consciência se constitui como consciência do mundo. Se cada consciência tivesse o seu mundo, as consciências se desencontrariam em mundos diferentes e separados seriam nômades incomunicáveis. As consciências não se encontram no vazio de si mesmas, pois a consciência é sempre, radicalmente, consciência do mundo.

Todavia, ao fazer o percurso para alcançar o estado emancipatório e libertador, na perspectiva crítica adorniana e freiriana, o educando aos poucos abandona os ancoradouros das convicções pedagógicas tradicionais que lhe dão sustentação intelectual cognitiva, mas não levam ao exercício educativo autocrítico para emancipar-se, libertar-se.

0 movimento de emancipação implica a crítica da pedagogia vigente em nome de uma formação humanizadora. Nesse esforço, o sujeito se defronta com a dúvida angustiante que precede a criação de um novo sentido existencial da educação capaz de refazer, reconduzir o espírito na direção do caminho emancipatório e libertador.

A educação tradicional vigente, em sua operação instrumental, embrutece, transforma o sujeito em quase objeto, mergulhando-o no todo indistinto da mistificação pedagógica. A libertação se faz pela conscientização, pela recuperação da vocação ontológica de ser mais, o que envolve sempre um ser com os outros, uma esfera da práxis intersubjetiva no mundo, considerado na sua materialidade superadora da pseudoconcreticidade.

\section{Possibilidade de superação da educação não crítica}

A expectativa da razão iluminista de que a educação seria um dos principais impulsionadores da emancipação foi se arrefecendo. A realidade histórica da primeira metade do século XX, e mesmo a posterior, levou Adorno a admitir a danificação do projeto de formação do esclarecimento e o advento da barbárie, inclusive como "lógica" subjacente às relações entre os indivíduos.

Não seria implausível reconhecer que o mundo capitalista se constituiu em um sistema de dominação e, por consequência, houve a quase supressão do pensamento crítico e dos espaços de resistência. Tal diagnóstico indicaria, portanto, a manutenção e mesmo o fortalecimento de uma educação que promove a adequação ao sistema, administrando condutas e se deixando administrar.

Um novo diagnóstico, no entanto, revela que o sistema de totalização da dominação mostra aos poucos interstícios e fissuras reveladores da possibilidade de exercício efetivo da consciência crítica. A emancipação mantém a sua potencialidade, mas, para que se 
compreenda esse movimento, é necessário realizar uma prestação de contas com o passado idealista e materialista do projeto de emancipação.

Assim, a autonomia assume a posição de pressuposto da emancipação. Entretanto, na crítica adorniana à totalidade e à identidade de sujeito e objeto, a singularidade do ente humano ganha o estatuto de componente fundamental de qualquer projeto de emancipação, sendo a força por meio da qual se pode erigir a resistência dos sujeitos.

Freire (1987) reconhece com insistência a relevância da pessoalidade, dos elementos singulares dos sujeitos, no processo de libertação. Sem abrir mão das ligações comunitárias e sociais, o pensador brasileiro se recusa a aceitar a dissolução da subjetividade e das suas particularidades em qualquer totalidade. Se é verdade que ninguém se educa na solidão, é igualmente necessário reconhecer que a educação não deve se impor de fora, heteronimamente, ainda que seja em nome de uma consciência coletiva. É absolutamente exigido de uma educação crítica, a adesão e a compreensão consciente do educando a qualquer projeto de libertação.

A conscientização é também um evento subjetivo, de modo que cada sujeito é agente da sua própria libertação, em ação compartilhada por múltiplas consciências esclarecidas que decidiram lutar juntas. Não se admite que haja apenas uma parcela da coletividade que porte a consciência da totalidade, cabendo aos demais atuar, durante o processo de libertação, como força ainda não esclarecida.

A educação emancipatória como projeto de um viver em comum não pode se sustentar na instrumentalização dos sujeitos, no uso de mecanismos discursivos descompromissados com o respeito ético às pessoas. Desse modo, por ser incompatível com esse projeto, recusa-se todo tipo de doutrinação ou manipulação das consciências.

Entretanto, sabe-se que a educação tradicional vigente, em certo sentido, não efetiva substancialmente a transformação no âmbito educacional e social, apesar dos avanços tecnológicos utilizados na aprendizagem do educando. Ao mesmo tempo, fica explícita a necessidade de uma consciência crítica libertadora para desarticular a opressão incorporada à formação dos sujeitos.

A crítica à realidade não deve ser desarticulada da autocrítica do sujeito. Assim, abala-se o dogmatismo e a posição de adesão ao existente, a aceitação subjetiva de uma condição de subalternidade que se constitui em obstáculo à superação da opressão da consciência colonizada que porta o opressor.

A emancipação não se efetiva, portanto, por um movimento mecânico, imediato, mas antes exige um processo complexo e dialético que envolve aspectos objetivos e subjetivos. Nas palavras de Freire (1987, p. 35): “A libertação, por isto, é um parto. É um parto doloroso. 0 homem que nasce deste parto é um homem novo que só é viável na e pela superação da contradição opressores-oprimidos, que é a libertação de todos”.

A libertação na trama crítica freiriana manifesta-se em uma práxis pedagógica desconstrutora, que opera em antítese à realidade opressora subjacente tanto ao opressor quanto ao oprimido. Por isso, ambos precisam de libertação, ainda que essa só se concretize pela luta tenaz e radical dos oprimidos.

0 ato pedagógico crítico e libertador não se dá no vácuo, mas nas relações entre os sujeitos sociais, na dinâmica tensional dos sujeitos entre si e com a realidade. Por isso, o pensamento 
freiriano reivindica a sua gênese e seu sentido nas experiências e vivências das pessoas. 0 sentido exige a apreensão intelectual, a interpretação da realidade, mas concomitantemente evoca a ação, a indicação de um sentido como direção e horizonte de humanização.

Assim, a práxis não repousa numa crítica ingênua e idealista, mas leva em conta a materialidade e corporeidade da vida e a objetividade dinâmica e inquietadora do mundo. Pode-se dizer que a emancipação ou libertação se efetivam pela educação, desde que esta seja compreendida como práxis que se constitui por si mesma como processo formativo.

A dimensão subjetiva dessa formação pressupõe um tipo de relação com a realidade que repercute como transformação do sujeito no trânsito da consciência mágica intransitiva, fechada em si mesma, para a consciência crítica, pensante, emancipadora e problematizadora, no terreno arenoso da realidade opressora e da educação tradicional, a fim de levar o educando a pensar sua saída e condição habitual de subalternidade. Freire (2016, p. 114) deixa evidente que, sem passar por essa transformação subjetiva, "A consciência dominada não se distancia o bastante da realidade para objetivá-la para que possa conhecê-la de maneira crítica [...]”.

Uma vez esclarecido o lugar da práxis na formação, é possível dimensionar a real relevância do ato pedagógico crítico-libertador no sentido assumido no pensamento freiriano. Embora não seja suficiente nem independente da ação no mundo, a reeducação do olhar ou da consciência é uma condição da libertação.

Da consciência adaptada e submersa no mundo, precisa emergir uma subjetividade problematizadora, aberta às possibilidades inéditas de um "ser mais" do sujeito, que pode ser vislumbrado e perseguido como projeto alcançável por um sujeito assumidamente livre e capaz de se autocriar no mundo com os outros. 0 mundo é encarado como construção histórica alterável, deixando de se impor ideologicamente como realidade que se sobrepõe de maneira absoluta aos entes humanos.

A superação do medo à liberdade e a consciência da historicidade do mundo já se constituem em parte do processo de emancipação, que inclui a reflexão, um voltar-se crítico do sujeito sobre si como sujeito histórico, que permite a cada um pensar como se formou e de que modo se consolidou o seu arcabouço intelectual no processo de aprendizagem.

A crítica, reflexão e autocriação do mundo, não é um ato que se efetiva e se encerra, mas um esforço constante e continuado que define mesmo o sentido de ser sujeito. Ontologicamente, o tempo por excelência desse ente humano inconcluso e inacabado não é o passado nem mesmo o presente, mas o futuro na sua contingência e abertura.

Essa visão antropológica freiriana, bem próxima da adorniana, não pode ser ignorada pelo educador emancipado e engajado no esforço de emancipação do outro com quem compartilha o mundo. Note-se, pois, que, sem cair em idealismo, é possivel sustentar ser nas profundezas da subjetividade em que se ocultam e se instalam as forças de dominação e domesticação, mas também as da resistência à opressão.

A realidade opressora se movimenta ideologicamente na pseudoconcreticidade, dissimula o estado de subalternidade em que se encontra o sujeito, que assimila acriticamente como natural o que é histórico e sociocultural. Kosik (1976, p. 15) alerta que "o mundo da pseudoconcreticidade é um claro-escuro de verdade e engano. 0 seu 
elemento próprio é o duplo sentido. 0 fenômeno indica a essência e, ao mesmo tempo, a esconde. A essência se manifesta no fenômeno, mas só de modo inadequado".

Ora, a perspectiva de uma educação libertadora e emancipadora não se pode expressar de modo distante da tensão da realidade opressora, devendo prescindir, por meio do seu movimento não linear e em seu fieri operativo, pedagógico e crítico, do mero "abstracionismo pedagógico" (AZANHA, 1992, p. 42) que impossibilita uma prática factual, o exercício do pensamento como uma força, e não uma substância pensante. Devido a isso, a educação pensada segundo os critérios adornianos e freirianos evidencia que os educadores devem abandonar posturas rígidas, meramente abstratas, e a ilusão de estabelecer "limites coercitivos" ao pensamento do educando. Assim, o discente poderá sair da "caverna" da educação tradicional e encontrar a sua liberdade, livrando-se da cegueira provocada pelas sombras pedagógicas tradicionais, para as quais os docentes seriam os únicos a verem a luz.

Entretanto, é preciso deixar explícito que a própria prática pedagógica instituída precisa ultrapassar seus princípios didatizados, tornando-se uma práxis aberta e dialógica, sem a pretensão de impor "dogmas" aos educadores e educandos. A educação libertadora deve se pronunciar como um ato filosófico transgressor e problematizador, que favorece a aprendizagem crítica do conhecimento científico, fazendo cair fronteiras cognitivas da tradição educativa.

Retomando a questão de fundo sobre a concepção da emancipação na educação em Adorno (1995), pode-se dizer que a educação tem o desafio de efetivar-se como formação cultural crítica (Bildung) para que o educando supere a realidade opressora, a menoridade intelectual e ético-política, tendo em vista que a sociedade do esclarecimento científico não conduziu o sujeito efetivamente à conquista da sua emancipação.

Adorno reafirma de forma categórica a necessidade fundamental de pensar a educação de forma crítica, mas não assume sem reparos o projeto da razão do iluminismo, inclusive nos seus desdobramentos posteriores, deixando claro a validade do esforço de retomar a racionalidade em um sentido ético-político emancipatório.

Nesse sentido, a educação deve preparar o educando para que se oriente no mundo circundante, mais precisamente no enfrentamento da realidade opressora, a fim de que não se deixe desorientar pelo mundo, mantendo, em certo sentido, sua singularidade. Enfatiza-se ainda, na ótica adorniana, que a educação, para articular a emancipação, deve partir do ponto lógico que pressupõe uma razão mais ampla do que a dos saberes formais e conteudistas derivados do corolário ideológico da pedagogia instituída, que visa não a adaptação do educando, mas sua emancipação do status quo.

Diante dos pontos elencados, observa-se a importância que a dimensão da resistência tem para Adorno, considerando que os sujeitos não são formados, mas antes se mostram praticamente adestrados e adaptados ao mundo circundante. Por isso, insiste que a educação tem a tarefa de despertar os sujeitos para resistirem às multifacetadas formas de subalternidade. Assim, a partir da compreensão crítica das relações de opressão, pretende-se que os sujeitos possam recriar, reinventar sua maneira própria de pensar, ser e agir no mundo.

Adorno (1995, p. 181-182) infere que: 
[...] a organização social em que vivemos continua sendo heterônoma, isto é, nenhuma pessoa pode existir na sociedade atual realmente conforme suas próprias determinações; enquanto isto ocorre, a sociedade forma as pessoas mediante inúmeros canais e instâncias mediadoras, de um modo tal que tudo absorvem e aceitam nos termos desta configuração heterônoma que se desviou de si mesma em sua consciência. É claro que isto chega até as instituições, até a discussão acerca da educação política e outras questões semelhantes. 0 problema propriamente dito da emancipação hoje é se e como a gente - e quem é "a gente”, eis uma grande questão a mais pode enfrentá-lo.

Entende-se que a questão da heteronomia, presente na atual sociedade e na educação, e mesmo na organização do mundo, continua heterônoma, traduzindo-se em ideologia dominante, aliciando e pressionando o sujeito pelos meios de comunicação de massa. Explicita-se na ótica filosófica adorniana que, no mundo, a educação vigente (Halbbildung) direciona-se não pela autonomia, mas pela força coercitiva da heteronomia. Adorno (2002, p. 43) assevera que:

A indústria cultural perfidamente realizou o homem como ser genérico. Cada um é apenas aquilo que qualquer outro pode substituir: coisa fungível, um exemplar. Ele mesmo como indivíduo é absolutamente substituível, o puro nada, e é isto que começa a experimentar quando, com o tempo, termina por perder a semelhança.

Em relação à emancipação-libertação nos moldes delineadores freirianos, esse quadro exposto reflete e critica a educação, tendo como foco central o educando, sua emancipação e autonomia, para gestar e conquistar sua cidadania intelectual e política diante da realidade opressora. Considera-se que a caminhada da humanidade tem por base a sua construção emancipatória. Assinala-se, do mesmo modo, que é na vivência do cotidiano e do anti-cotidiano que a Pedagogia do oprimido se mostra mais dialógica, transgressora e libertadora, pois o cotidiano reflete as relações de poder no mundo ao qual o sujeito está vinculado.

Embora a crítica e a perspectiva filosófica sejam pertinentes como parte integrante da práxis pedagógica dialógica freiriana, não podem ser um "absoluto pedagógico", mas uma condição para o exercício do pensamento, evitando certo enrijecimento cognitivo ou dogmatismo, que impossibilita o exercício pedagógico libertador-emancipador. A proposta teórica-crítica freiriana não se pauta "num fundamento estático", mas se movimenta num processo dinâmico, propondo sempre a ruptura com o habitual e o trivial.

Já que a desumanização é fato histórico, e considera-se a humanização como vocação humana, o homem é projeto para ser mais. Se a ordem social não possibilita essa condição existencial, ela expressa enfaticamente um traço contraditório com a natureza humana, ficando explícita sua anomalia e injusta denegação do "outro", que tem o direito de "ser mais" em sua humanidade.

Na medida em que vai se pautando a proposta de se instaurar a emancipação do educando, compreende-se que o ser humano como um todo é um ser aberto e que a "intransitividade" não o encerra no fechamento sobre si mesmo. Diante da realidade 
opressora do mundo circundante, o "ser menos" do ente humano representa uma séria dificuldade para que se possa discernir com mais profundidade e nitidez sua atuação como sujeito social dentro de uma perspectiva libertadora-emancipatória.

No entanto, o sujeito social pode fazer a passagem da consciência intransitiva à consciência transitiva crítica que propõe o diálogo educativo, problematizando sempre e voltando-se para a responsabilidade social, política, ideológica e cultural, sem escamotear as fixações pedagógicas, mas tomando consciência e distanciamento dessas fixações, sabendo interpretar com mais propriedade o contexto social e suas demandas, e não se deixando reduzir à instância do trabalho, embora necessite dele para subsistir e viver bem com os outros.

No que tange ao princípio basilar da emancipação e autonomia do sujeito, faz-se necessária a intrépida operação crítica como ato emancipador, determinando suas diretrizes pedagógicas para incentivar o educando ao exercício de sua cidadania ético-política, não permitindo sua fixidez intelectual aos parâmetros da pedagogia opressora, mas antes provocando inquietação para que não se forme um sujeito subjugado, desumanizado.

Freire (2017, p. 82) esclarece que:

A medida, porém, que amplia o seu poder de captação e de resposta às sugestões e às questões que partem de seu contorno e aumenta o seu poder de dialogação, não só com o outro homem, mas com o seu mundo, se "transitiva". Seus interesses e preocupações, agora, se alongam a esfera mais ampla do que a simples esfera vital.

Todavia, sabe-se que esse processo da conscientização não se dá de modo ingênuo, pois o sujeito deve edificar sua existência social, mesmo sob o risco de fazer o movimento vital contrário aos ideários pedagogizados. Le Bon (2008, p. 34) adverte que, "na alma coletiva, apagam-se as aptidões intelectuais dos homens e consequentemente sua individualidade, 0 heterogêneo perde-se no homogêneo e as qualidades inconscientes dominam”. Esse fato é imprescindivel para interpretar a proposta pedagógica crítica freiriana, mas principalmente para compreender a filosofia adorniana acerca da formação emancipatória.

\section{Considerações finais}

Adorno e Freire mostram a necessidade de questionar qualquer projeto educativo que trate as pessoas como se fossem coisas, objetos sem autonomia e, por isso, incapazes de pensar por conta própria, de decidir acerca de seu próprio ser ou de sua realidade social.

Esses autores recusam a formação humana que se sustenta na obediência cega à autoridade, seja da tradição como "coisa dada", do Estado como totalidade sintetizadora dos interesses gerais ou de qualquer outra instância fundamentalista que vede a crítica e imponha limites ao exercício do questionamento.

De nenhuma forma se pode admitir a doutrinação, a ação constitutiva das subjetividades por meio de mecanismos irracionais, violentos, intimidadores e limitadores da liberdade de pensamento e de modos de ser. 
Um projeto formativo só emancipa se consegue reconhecer e levar a efeito ações educativas comprometidas com a autonomia e a liberdade dos sujeitos, nas diversas instâncias públicas nas quais se debate os interesses da vida em comum em conexão com a diversidade axiológica, ético-política e epistêmica.

Os fundamentalismos dogmáticos, visões absolutas e exclusivistas de mundo, não podem se impor como verdades indiscutíveis nos espaços públicos, inclusive naqueles que se dedicam primordialmente aos processos formais de ensino e aprendizagem. Caso prevaleça esse tipo de posicionamento como eixo orientador da educação, a emancipação se manifestará como esforço de resistência contra a regressão da humanização.

A autoridade das instâncias educativas da sociedade não pode se amparar, caso queira ampliar e radicalizar a democracia, em mecanismos de repressão ao livre pensar e ser; nem na limitação do que pode ou não ser questionado; tampouco na imposição de uma única cosmovisão como representante autorizada, por alguma instância de poder instituída, do que é ou não a realidade.

0 diálogo entre indivíduos e grupos, assim como a valorização da pluralidade de formas de vida, são condições que precisam ser fomentadas em prol de uma educação comprometida com a liberdade, autonomia e emancipação definidas como construção histórica, social, político e cultural. Assim, torna-se necessário diagnosticar os interstícios e explorar os possíveis espaços a partir dos quais, nos diversos momentos históricos, é possível construir a emancipação.

Note-se, pois, que a emancipação se dá como exercício de pensamento, podendo adquirir, em Adorno, a propriedade de "práxis". No entanto, a ação de pensar, por mais que produza mudanças e forme os sujeitos, interferindo na sua autoconstituição, exige um ir além de si, na sua particularidade, de modo a encontrar os outros seres pensantes e o mundo. Assim, a práxis amplia-se como interconexão do pensar e do agir com os outros e, nesse movimento relacional, são produzidas determinadas mudanças em todos os envolvidos na relação, como defendeu Freire (1987).

Muito embora a relação entre teoria e transformação e vice-versa, e entre pensamento e ação sejam imprescindíveis à emancipação, não se pode minimizar o lugar da crítica dirigida aos conceitos, às construções linguísticas e simbólicas, na medida em que têm um potencial formativo inegável. A emancipação realiza-se também no exame rigoroso dos discursos, dos conceitos, dos jargões, slogans e memes que, reificados, dispensam o esforço de pensar, sufocam o questionamento e sacrificam a argumentação.

Sabe-se com a mesma clareza que a análise crítica desenvolvida no âmbito simbólico necessita de instâncias públicas, considerando-se, inclusive, o espaço educacional formal na sua publicidade. A liberdade e a autonomia se vinculam à emancipação como dimensão ético-política da existência e não se confundem com o livre-arbítrio e a liberdade de consciência do indivíduo como tal.

0 próprio diálogo define-se pela abertura ao outro, que pressupõe o espaço público, a publicidade da palavra, o exame dos argumentos, a crítica franca e não estratégica, pois a razão emancipatória dispensa subterfúgios e a imposição da "verdade" ao outro a qualquer custo, apoiando-se, ao contrário, na autêntica comunicação. 
Pode-se reconhecer, portanto, a centralidade das ações educativas que se desenvolvem na sociedade, uma das condições fundamentais para que a emancipação se constitua, particularmente nas instituições formais de educação. Contudo, explicitou-se também que o pensar por conta própria precisa ir além do âmbito restrito da individualidade, devendo alcançar as instâncias públicas nas quais as subjetividades se constituem ética e politicamente.

No que concerne ao lugar da razão, essa não deve ser abandonada no seu potencial fomentador de formação humana crítica, pois, para além da instrumentalidade técnicocientificista predominante na sociedade capitalista tardia, ainda é possível pensar no compromisso dos educadores e educandos com a emancipação como finalidade da educação.

\section{Referências}

ADORNO, Theodor W. Dialética negativa. Tradução Marco Antonio Casanova. Rio de Janeiro: Zahar, 2009. ADORNO, Theodor W. Educação e emancipação. Tradução Wolfgang Leo Maar. 4. ed. Rio de Janeiro: Paz e Terra, 1995.

ADORNO, Theodor W. Indústria cultural e sociedade. 5. ed. Rio de Janeiro: Paz e Terra, 2002.

ADORNO, Theodor W.; HORKHEIMER, Max. Dialética do esclarecimento: fragmentos filosóficos. Tradução Guido Antonio de Almeida. Rio de Janeiro: Zahar, 1985.

AZANHA, José Mario Pires. Uma ideia de pesquisa educacional. São Paulo: USP, 1992.

FREIRE, Paulo. Conscientização. Tradução Thiago José Resileme. São Paulo: Cortez, 2016.

FREIRE, Paulo. Educação como prática de liberdade. 40. ed. Rio de Janeiro: Paz e Terra, 2017.

FREIRE, Paulo. Pedagogia do oprimido. Rio de Janeiro: Paz e Terra, 1987.

FREUD, Sigmund. 0 mal-estar na civilização. Tradução Paulo César de Souza. São Paulo: Companhia das Letras, 2010.

FREUD, Sigmund. Psicologia das massas e análise do eu e outros textos. Tradução Paulo César de Souza. São Paulo: Companhia das Letras, 2011.

HEGEL, Georg Wilhelm Friedrich. Fenomenologia do espírito. Tradução Paulo Meneses. 2. ed. Petrópolis: Vozes, 1992. pt. 1.

KOSIK, Karel. Dialética do concreto. Tradução Célia Neves e Alderico Toríbio. 7. ed. Rio de Janeiro: Paz e Terra, 1976.

LE BON, Gustave. Psicologia das multidões. Tradução Maria Sérvila da Cunha. São Paulo: Martins Fontes, 2008. 
NIETZSCHE, Friedrich. 0 nascimento da tragédia ou helenismo e pessimismo. Tradução J. Guinsburg. São Paulo: Companhia das Letras, 1992.

ZUIN, Antônio Álvares Soares; PUCCI, Bruno; OLIVEIRA, Newton Ramos de. Adorno: o poder educativo do pensamento crítico. 2. ed. Petrópolis: Vozes, 1999.

Recebido em: 04.06.2020

Revisado em: 06.08.2020

Aprovado em: 01.09.2020

Damião Bezerra Oliveira é graduado em filosofia (1996), mestre (2007) e doutor (2013) em educação pela Universidade Federal do Pará (UFPA). É docente da Faculdade de Filosofia da UFPA e do Programa de Pós-graduação em Educação (PPGED-UFPA).

Izan Rodrigues de Souza Fortunato é mestre (2019) e doutorando (2020) em educação pelo Programa de Pós-graduação em Educação (PPGED-UFPA), e especialista em filosofia da educação (2015) pela UFPA.

Waldir Ferreira de Abreu tem pós-doutorado em ciências da educação - CU/Brasil-Espanha (2013), é doutor em ciências humanas e educação (2010) pela Pontifícia Universidade Católica do Rio de Janeiro (PUC-Rio), mestre em educação e políticas públicas (2002) pela UFPA, e docente do PPGED-UFPA. 